ARTIKEL

\title{
PENGEMBANGAN LEMBAR KERJA PESERTA DIDIK (LKPD) DALAM PEMBELAJARAN TEKS EKSPLANASI KOMPLEKS KELAS XI SMA NEGERI 20 MEDAN TAHUN PEMBELAJARAN
} 2016/2017

\author{
Oleh \\ Risma Tulan Sinurat \\ NIM 2131111045 \\ Dosen Pembimbing Skripsi \\ Dr. Syahnan Daulay, M.Pd.
}

Telah Diverifikasi dan Dinyatakan Memenuhi Syarat untuk Diunggah pada Jurnal Online

Editor,

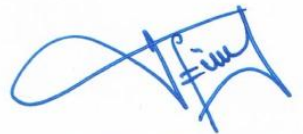

Fitriani Lubis, S.Pd., M.Pd. NIP. 197708312008122001
Medan, Juli 2017 Menyetujui :

Dosen Pembimbing Skripsi,

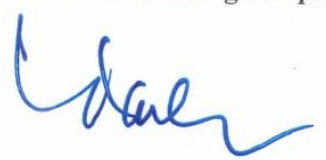

Dr. Syahnan Daulay, M.Pd. NIP. 195808311986011002 


\title{
PENGEMBANGAN LEMBAR KERJA PESERTA DIDIK (LKPD) \\ DALAM PEMBELAJARAN TEKS EKSPLANASI KOMPLEKS KELAS XI SMA NEGERI 20 MEDAN TAHUN PEMBELAJARAN 2016/2017
}

\author{
Oleh \\ Risma Tulan Sinurat \\ Dr. Syahnan Daulay, M.Pd.
}

Hasil penelitian menunjukkan bahwa pengembangan lembar kerja peserta didik (LKPD) untuk pembelajaran teks eksplansi kompleks siswa kelas XI SMA Negeri 20 Medan Tahun Pembelajaran 2016-2017.Tergolong dalam kategori "Sangat Baik". Dapat dilihat dari hasil rata-rata penilaian tim ahli materi yang memperoleh skor $87,7 \%$ yang dapat dikategorikan sangat baik. Hal tersebut dapat dilihat dari kelayakan isi materi, kelayakan penyajian, kelayakan bahasa. Hasil dari penilaian tim ahli desain memperoleh skor $92 \%$ yang dikategotikan sangat baik. Hal ini dapat dilihat dari kelayakan kegrafikan LKPD. Dan hasil penilaian dari materi selaku guru bidang studi memperoleh skor $87,7 \%$ yang dapat dikategorikan sangat baik. Hal tersebut dapat dilihat dari kelayakan isi materi, kelayakan penyajian, kelayakan bahasa. Dan diperkuat dari hasil uji coba produk pada uji coba kelompok kecil yang mencapai skor $80,73 \%$ dan uji coba kelompok besar dengan skor $82,41 \%$ yang dapat dikategorikan sangat baik. Dengan demikian dapat disimpulkan bahwa lembar kerja peserta didik (LKPD) pada pembelajaran teks eksplanasi kompleks layak dan efektif digunakan.

Kata kunci :Pengembangan Lembar Kerja Peserta Didik (LKPD), Model Plom, Teks Eksplanasi Kompleks.

\section{PENDAHULUAN}

Proses belajar mengajar akan berjalan efektif dan efisien bila didukung dengan tersedianya bahan ajar atau alat bantu yang menunjang. Penyediaan bahan ajar serta metodologi pendidikan yang dinamis, kondusif serta dialogis sangat diperlukan bagi pengembangan potensi siswa secara optimal. Potensi siswa akan muncul bila dibantu dengan sejumlah bahan ajar atau alat bantu yang mendukung proses interaksi yang sedang dilaksanakan. 
Penggunaan Lembar Kerja Peserta Didik (LKPD) diharapkan mampu mengubah kondisi pembelajaran dari yang biasanya guru menentukan "apa yang dipelajari" menjadi bagaimana menyediakan dan memperkaya pengalaman belajar siswa. Penyajian pembelajaran Bahasa Indonesia dengan menggunakan LKPD menuntut adanya partisipasi aktif dari para siswa. Karena LKPD merupakan bentuk usaha guru untuk membimbing siswa secara terstruktur, melalui kegiatan yang mampu memberikan daya tarik kepada siswa untuk mempelajari Bahasa Indonesia.

Dengan demikian, pada saat pembahasan meteri di kelas, siswa sudah siap dengan bekal informasi dan pengetahuan yang cukup sehingga waktu belajar yang tersedia tidak lagi digunakan guru untuk menjelaskan materi secara panjang lebar, melainkan lebih banyak digunakan untuk diskusi dan mebahas materi-materi tertentu yang belum dipahami siswa.

Pengembangan lembar kerja peserta didik ini nantinya bisa digunakan siswa untuk belajar secara mandiri dengan atau tanpa bimbingan guru.LKPD yang dikembangkan berisi materi tentang teks eksplanasi kompleks. Pada kurikulum 2013, memahami teks eksplanasi kompleks terdapat pada pembelajaran kelas XI SMA. Berikut disajikan tabel kompetensi inti dan kompetensi dasar pada pembelajaran Bahasa Indonesia.

Tabel 1.1

KI dan KD Pada Pembelajaran Bahasa Indonesia Kelas XI SMA/MA

\begin{tabular}{|l|lr|}
\hline 3. Memahami, menerapkan, & 3.1 Memahami struktur dann kaidah \\
menganalisis, dan mengevaluasi & teks eksplanasi kompleks, baik lisan \\
pengetahuan faktual, konseptual, & maupun tulisan. \\
prosedural, dan metakognitif & 3.1 .1 Mengetahui struktur teks \\
berdasarkan raasa ingin tahunya & eksplanasi kompleks. \\
tentang ilmu pengetahuan teknologi, & $\begin{array}{l}3.1 .2 \text { Mengetahui kaidah teks } \\
\text { seni, budaya dan humaniora. }\end{array}$ & eksplanasi kompleks. \\
\hline
\end{tabular}

Penggunaan LKPD dalam pembelajaran juga dapat membantu minat siswa dalam pembelajaran. Dari hasil wawancara saya terhadap bapak Edy Riswanto, S.Pd, selaku guru mata pelajaran Bahasa Indonesia kelas XI MS SMA Negeri 20 Medan. Beliau mengatakan bahwa "LKPD Bahasa Indonesia dikelas XI SMA Negeri 20 Medan masih tergolong biasa saja (tidak menarik)." Jadi minat siswa dalam belajar tidak ada 
dan mereka merasa bosan melihat tampilan LKPD mereka. LKPD juga membantu menumbuh kembangkan minat siswa apa lagi saat guru yang mengajar juga membosankan, maka pembelajaran tidak akan berjalan lancar. Kemudian sependapat dengan beliau, Ibu Mahanim, S.Pd, selaku guru Bahasa Indonesia kelas XI IS SMA Negeri 20 Medan juga mengatakan bahwa nilai siswa dalam mengerjakan tugas yang ada di lembar kerja peserta didik dalam buku teks masih tergolong rendah. Dikarenakan siswa kurang minat dengan lembar kerja peserta didik (LKPD).

Sangat diperlukan pengembangan bahan ajar dalam meningkatkan minat belajar siswa. Pengembangan berarti menciptakan sesuatu yang baru atau mengembangkan konsep yang telah ada menjadi lebih baik dengan inovasi. Penelitian ini akan mengembangkan bahan ajar berupa LKPD dalam materi teks eksplanasi komplesk untuk siswa kelas XI. Pengembangan ini nantinya dapat digunakan sebagai tambahan materi atau referensi buku teks Bahasa Indonesia yang sudah ada.

Berdasarkan uraian yang telah dipaparkan, maka penulis mengangkat judul penelitian yang dituangkan dalam bentuk karya tulis yang berjudul "Pengembangan Lembar Kerja Peserta Didik (LKPD) Dalam Pembelajaran Teks Eksplanasi Kompleks Kelas XI SMA Negeri 20 Medan Tahun Pembelajaran 2016/2017.”

\section{METODE PENELITIAN}

Penelitian ini menggunakan metode penelitian dan pengembangan (research and development/R\&D). Research and Development adalah metode penelitian yang digunakan untuk menghasilkan produk tertentu, dan menguji keefektifan produk tersebut (Sugiyono, 2013:407). Peneliti menggunakan metode Research and Development karena metode ini sangat sesuai untuk penelitian ini yang bertujuan untuk menghasilkan suatu produk tertentu yang bersifat analisis kebutuhan dan untuk menguji keefektifan produk yang akan dihasilkan. Produk yang diharapkan dalam penelitian ini adalah LKPD teks eksplanasi kompleks yang dipakai dalam pembelajaran teks eksplanasi kompleks di kelas XI SMA Negeri 20 Medan. 


\section{HASIL PENELITIAN DAN PEMBAHASAN}

\section{a. Hasil Penelitian}

\section{Deskripsi Hasil LKPD}

\section{a. Hasil Telaah Tentang Pentingnya LKPD}

Proses pertama kegiatan pengembangan ini adalah dengan melakukan analisis kebutuhan di SMA Negeri 20 Medan. Analisis kebutuhan tersebut dilakukan dengan cara memberikan angket kepada 30 orang siswa dan satu orang guru Bahasa Indonesia di kelas XI tentang pengenalan lembar kerja peserta didik (LKPD) dalam materi teks eksplanasi kompleks.

Dari hasil data simpulkan bahwa sebagian siswa dan guru sudah mengenal bagaimana lembar kerja peserta didik (LKPD) dengan skor 96, 77\%, dan juga 100\% tidak menggunakan lembar kerja peserta didik (LKPD) dalam proses pembelajaran tentang memahami teks eksplanasi kompleks. Selanjutnya 96,77\% guru dan siswa memerlukan lembar kerja peserta didik (LKPD) dalam proses pembelajaran tentang materi teks eksplanasi kompleks

\section{b. Fase Desain (design)}

\section{Tampilan Sampul Depan dan Belakang LKPD}

Tampilan sampul pada lembar kerja peserta didik (LKPD) ini yang dibuat dengan Corel Draw dapat dilihat seperti pada gambar berikut ini.

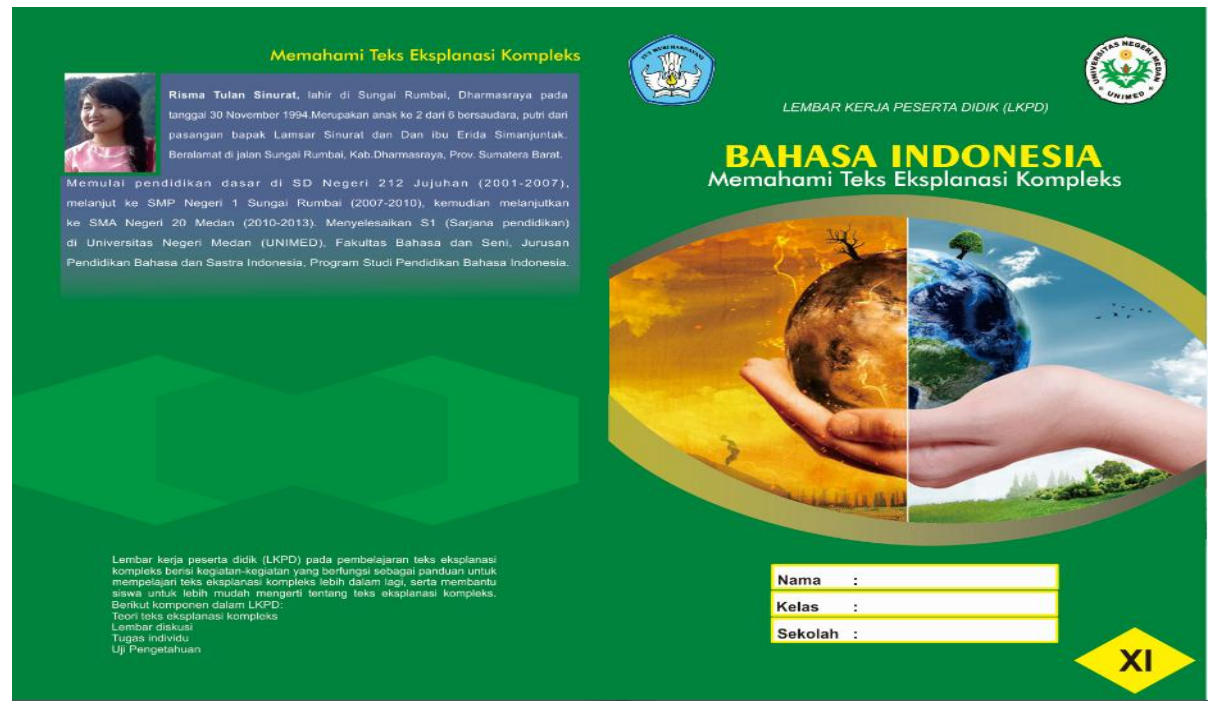

Gambar: Tampilan Sampul LKPD 


\section{Data Hasil Validasi}

\section{Validasi Desain}

Validasi desain terhadap lembar kerja peserta didik (LKPD) pada materi teks eksplanasi kompleks yang dilakukan oleh satu orang ahli desain yakni bapak Drs. Gamal Kartono, M.Si., dosen Seni Rupa Universitas Negeri Medan. Validasi dilakukan untuk meningkatkan kelayakan LKPD dengan cara memberikan angket kepada ahli desain untuk mendapatkan penilaian terhadap lembar kerja peserta didik (LKPD).

Berdasarkan hasil penilaian dari ahli desain pembelajaran tentang kelayakan tampilan dan kriteria fisik lembar kerja peserta didik (LKPD) pada materi teks eksplanasi kompleks secara keseluruhan dinilai Sangat Baik dengan hasil persentase 92\%. Hasil validasi terhadap lembar kerja peserta didik (LKPD) dapat dipersentasekan pada tabel berikut.

Perolehan nilai di atas menunjukkan bahwa penilaian ahli desain pada aspek tampilan dan kriteria fisik dinyatakan Sangat Baik dengan persentase $\mathbf{9 2 \%}$ namun masih terdapat catatan perbaikan yang perlu direvisi agar menghasilkan lembar kerja peserta didik (LKPD) yang memenuhi kualitas persyaratan kelayakan produk.

\section{Validasi Materi}

Validasi materi terhadap lembar kerja peserta didik (LKPD) pada materi pembelajaran teks eksplanasi kompleks yang dilakukan oleh satu orang ahli materi yakni ibu Dra. Rosmaini, M.Pd., dosen Bahasa Indonesia Universitas Negeri Medan. Validasi dilakukan untuk mengetahui kelayakan isi, kelayakan penyajian, daan kelayakan bahasa pada lembar kerja peserta didik (LKPD). Dengan cara memberikan angket kepada ahli desain untuk mendapatkan penilaian terhadap lembar kerja peserta didik (LKPD). Hasil validasi berupa skor dapat dilihat dari tabel berikut ini.

Berdasarkan hasil penilaian dari ahli materi tentang lembar kerja peserta didik (LKPD) tentang aspek kelayakan materi/isi pada pembelajaran teks eksplanasi kompleks, secara keseluruhan dinilai Sangat Baik dengan hasil persentase $\mathbf{9 2 \%}$. 
Hasil validasi terhadap lembar kerja peserta didik (LKPD) dapat dipersentasekan pada tabel berikut.

Berdasarkan hasil penilaian dari ahli materi tentang lembar kerja peserta didik (LKPD) tentang aspek kelayakan penyajian pada pembelajaran teks eksplanasi kompleks, secara keseluruhan dinilai Sangat Baik dengan hasil persentase 91,1\%.

Berdasarkan hasil penilaian dari ahli materi tentang lembar kerja peserta didik (LKPD) yang terdapat pada tabel 4.8 tentang aspek kelayakan bahasa pada pembelajaran teks eksplanasi kompleks, secara keseluruhan dinilai Baik dengan hasil persentase $\mathbf{8 0 \%}$.

Perolehan nilai di atas menunjukkan bahwa penilaian ahli materi pada aspek kelayakan materi, kelayakan penyajian dan kelayakan bahasa dinyatakan Sangat Baik dengan persentase $\mathbf{8 7 , 7 \%}$ namun masih terdapat catatan perbaikan yang perlu direvisi agar menghasilkan lembar kerja peserta didik (LKPD) yang memenuhi kualitas persyaratan kelayakan produk.

\section{b. Pembahasan Hasil Penelitian}

\section{Pentingnya Penggunaan Lembar Kerja Peserta Didik (LKPD) Materi teks} Eksplanasi Kompleks

Penelitian pengembangan produk yang telah dilakukan ini diarahkan untuk menghasilkan suatu produk berupa lembar kerja peserta didik (LKPD) pada pelajaran teks eksplanasi kompleks untuk siswa kelas XI SMA Negeri 20 Medan. Lembar kerja peserta didik (LKPD) ini dapat digunakan untuk meningkatkan proses pembelajaran dan kompetensi yang dimiliki oleh peserta didik. Dalam proses penyusunan lembar kerja peserta didik (LKPD) ini diawali dengan fase investigasi awal, kemudian fase desain lembar kerja peserta didik (LKPD), melakukan validasi produk kepada ahli desain, ahli materi dan guru SMA Negeri 20 Medan bidang studi Bahasa Indonesia.Pengguna lembar kerja peserta didik (LKPD) bertujuan untuk menghasilkan lembar kerja peserta didik (LKPD) yang layak dan efektif digunakan.

Manfaat pengembangan lembar kerja peserta didik (LKPD) dalam materi pembelajaran teks eksplanasi kompleks adalah menjadi sumber belajar yang mudah dipahami, sistematis, dan menarik minat siswa. Lembar kerja peserta didik (LKPD) 
ini terdiri dari latihan soal yang bervariasi, perpaduan warna yang manarik dan penjelasan materi yang singkat.

\section{Kelayakan Lembar Kerja Peserta Didik (LKPD) Materi Teks Eksplanasi Kompleks}

Kelayakan lembar kerja peserta didik (LKPD) secara teoritis dinilai berdasarkan hasil rata-rata dari aspek yang telah ditentukan yaitu kelayakan tampilan oleh ahli desain. Kelayakan isi, kelayakan penyajian dan kelayakan bahasa oleh ahli materi dan satu orang guru SMA Negeri 20 Medan mata pelajaran Bahasa Indonesia. Hasil nilai rata-rata penilaian dari ahli desain berkategori Sangat Baik dengan nilai ratarata 92, sedangkan penilaian dari ahli materi berkategori Sangat Baik dengan nilai rata-rata 87,7, selanjutnya penilaian dari guru Bahasa Indonesia SMA Negeri 20 Medan berkategori Sangat Baik dengan nilai rata-rata 87,7. Dari semua hasil nilai rata-rata penilaian terhadap lembar kerja peserta didik (LKPD), dapat disimpulkan bahwa lembar kerja peserta didik (LKPD) yang telah dikembangkan layak untuk digunakan dengan kategori Sangat Bagus dan nilai rata-rata 89,13.

\section{Keefektifan Lembar Kerja Peserta (LKPD) Materi Teks Eksplanasi Komplek}

Lembar kerja peserta didik (LKPD) yang telah dikembangkan pada materi pembelajaran memahami teks eksplanasi kompleks yang telah diuji cobakan melalui dua tahap,uji coba kelompok kecil dan uji coba kelompok besar. sehingga menghasilkan lembar kerja peserta didik (LKPD) yang layak dan efektif digunakan sesuai dengan bidang studi yang dibahas. Uji coba kelompok kecil yang telah dilakukan, diperolah nilai rata-rata kemampuan siswa dalam menjawab soal tugas kelompok 85, tugas individu 79,2, dan uji pengetahuan 78. Sedangkan Uji coba kelompok besar yang telah dilakukan, diperolah nilai rata-rata kemampuan siswa dalam menjawab soal tugas kelompok 82,5, tugas individu 84,25 dan uji pengetahuan 80,5. Dapat disimpulkan bahwa lembar kerja peserta didik (LKPD) yang telah diujikan efektif digunakan dengan kategori Sangat Baik dan nilai ratarata $81,57$. 


\section{PENUTUP}

Berdasarkan rumusan, tujuan, hasil dan pembahasan penelitian bahan ajar dalam bentuk lembar kerja peserta didik (LKPD) pada pembelajaran teks eksplanasi kompleks yang dikemukakan sebelumnya maka dapat disimpulkan sebagai berikut. Pengembangan lembar kerja peserta didik (LKPD) pada materi pembelajaran teks eksplanasi kompleks memang sangat dibutuhkan oleh guruh dan siswa pada proses pembelajaran. Terlihat dari hasil penyebaran angket yang menyatakan bahwa $\mathbf{9 5 , 6 6 \%}$ sangat membutuhkan lembar kerja peserta didik (LKPD) dalam proses pembelajaran.Hasil validasi dari ahli desain, ahli materi dan guru bidang studi Bahasa Indonesia terhadap penilaian lembar kerja peserta didik (LKPD) pada pembelajaran teks eksplanasi kompleks yang dikembangkan menunjukkan bahwa penilaian secara keseluruhan dikategorikan "Sangat Baik" dengan nilai skor rata-rata $\mathbf{8 9 , 1 3 \%}$. Kelayakan lembar kerja peserta didik (LKPD) dari aspek tampilan oleh ahli desain dengan nilai skor 92\%, aspek kelayakan isi, penyajian, dan bahasa oleh ahli materi dengan nilai skor $87,7 \%$, dan aspek penilaian oleh guru bidang studi Bahasa Indonesia dengan skor $87,7 \%$. Hasil uji coba lembar kerja peserta didik (LKPD) yang telah diujikan kepada 30 siswa dengan dua tahap yaitu uji coba kelompok kecil sebanyak 10 siswa dengan hasil nilai rata-rata 80,73yang dikategorikanBaik, dan uji coba kelompok besar sebanyak 20 siswadengan hasil nilai rata-rata 82,41yang dikategorikan Sangat Baik. Maka dari hasil uji coba produk dinyatakan bahwa lembar kerja peserta didik (LKPD) layak dan efektif digunakan dengan kategori Sangat Baik dan skor nilai akhir rata-rata $81,57$.

\section{DAFTAR PUSTAKA}

Arikunto, Suharsimi. 2010. Prosedur Penelitian Suatu Pendekatan Praktis. Jakarta: Rineka Cipta.

Arsyad, Azhar. 2009. Media Pembelajaran. Jakarta: Rajawali Pres.

Depdiknas. 2013. Kurikulum Mata Pelajaran Bahasa Indonesia. Depdiknas, Jakarta.

Kemendikbud. 2013. Materi Pelatihan Implementasi Kurikulum 2013. Jakarta: Kemendikbud. 
Kosasih, E. 2014. Jenis-Jenis Teks dalam Mata Pelajaran Bahasa Indonesia $S M A / M A / S M K$. Bandung: Yrama Widya.

Majib, A. 2008. Perencanaan Pembelajaran Mengembangkan Standar Kompetensi Guru. Bandung: PT Remaja Rosdakarya.

Sugiyono, 2011.Metode Penelitian Kuantitatif, Kualitatif dan R\&D.Bandung: Alfabeta.

Sugiyono. 2013. Metode Penelitian Pendidikan. Bandung: Alfabeta

Sujadi, 2003. Metodologi Penelitian Pendidikan. Jakarta. Rineka cipta

Sukmadinata, Nana Syaodih. 2005. Metode Penelitian Pendidikan. Bandung: Rosdakarya. 